Journal of Dairy Research

cambridge.org/dar

\section{Research Reflection}

Cite this article: Barth K (2020). Effects of suckling on milk yield and milk composition of dairy cows in cow-calf contact systems. Journal of Dairy Research 87(S1), 133-137. https://doi.org/10.1017/S0022029920000515

Received: 17 October 2019 Revised: 27 February 2020 Accepted: 1 March 2020

\section{Key words:}

Performance; milk quality; calf rearing; milking frequency

Author for correspondence: Kerstin Barth,

Email: kerstin.barth@thuenen.de

\title{
Effects of suckling on milk yield and milk composition of dairy cows in cow-calf contact systems
}

Kerstin Barth

Institute of Organic Farming, Johann Heinrich von Thünen-Institute, Federal Research Institute for Rural Areas, Forestry and Fisheries, Trenthorst 32, 23847 Westerau, Germany

\begin{abstract}
In this research communication I show the effect of various cow-calf contact systems on milk yield and milk composition during the periods when calves where allowed to suckle their dams and after the calves were separated in comparison to cows that were only machine milked throughout their lactation. Analyses were based on four different experiments, but conducted at the same research station and under comparable housing and feeding conditions. Nursing dams had contact to their calves during the whole day, during night-time or only twice per day shortly before milking. A control group of cows that had no contact to their offspring was part of every experiment. Data of the regular monthly milk recordings were analysed with linear mixed models. Results showed a significant effect of the suckling system on the machine milk yield over the whole lactation. While cows with night-time contact reached the milk production level of the control cows, cows with whole day or short-time contact still produced less milk after the calves were separated. Fat content was always lower during the suckling period but not afterwards. The significantly higher milk protein content in dams with calf contact requires further investigation. Somatic cell count in milk of nursing dams was slightly increased, probably due to the exposure of the teats to frequent suckling in addition to machine milkings. In conclusion, cow-calf contact systems influence the performance of cows during and after the suckling period but to varying degrees depending on the system adopted.
\end{abstract}

(c) The Author(s), 2020. Published by Cambridge University Press on behalf of Hannah Dairy Research Foundation. This is an Open Access article, distributed under the terms of the Creative Commons Attribution licence (http://creativecommons.org/licenses/ by/4.0/), which permits unrestricted re-use, distribution, and reproduction in any medium, provided the original work is properly cited.
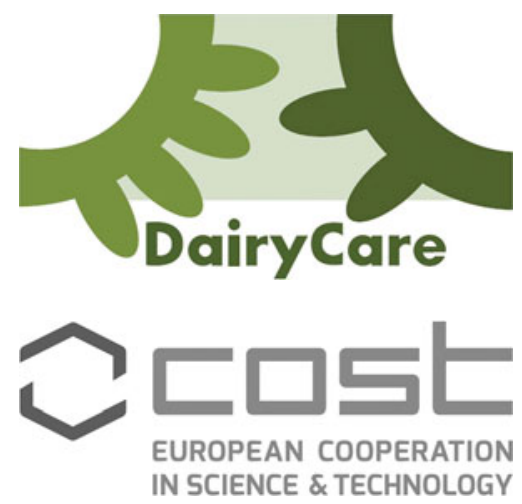

Funded by the Horizon 2020 Framework Programme of the European Union

Hannah Dairy Research Foundation

\section{CAMBRIDGE UNIVERSITY PRESS}

The separation of cow and calf immediately after birth, as common in dairy farms, is not widely accepted by consumers (Busch et al., 2017) and is a point of criticism in society's discussion about practices in modern farming. Meanwhile, a very small but increasing number of dairy farmers allow dams to nurse their calves and cow-calf contact (CCC) systems become more and more an object of research. Two recent papers analysed the current state of knowledge and showed that some often named obstacles to apply CCC systems, such as the risk of disease transmission between cow and calf, are not well supported by scientific evidence (Beaver et al., 2019), while others, such as the decreasing amount of saleable milk, seem to be well investigated (Meagher et al., 2019). However, CCC systems practiced on dairy farms as well as in experiments can vary considerably in time spans and time points when cows are allowed to suckle. This leads to variation in the frequencies of milk removal and their temporal distances to machine milking. Therefore, this study merged data of four experiments, which were conducted under the same housing and milking conditions, to explore the effect of three cow-calf contact systems on milk yield and milk composition over the whole lactation of dairy cows.

\section{Materials and methods}

The study included four experiments concerning cow-calf contact systems. All experiments were conducted at the research station of the Thünen-Institute of Organic Farming in Northern Germany between 2007 and 2014. Three of the four studies focused on calves' welfare (Roth et al., 2009; Wagner et al., 2013; Barth et al., 2015) and one investigated the milking behaviour of cows that nursed their calf between the regular milking times (Zipp et al., 2016).

\section{Animals and management}

The research farm is managed according to the EU regulation No. 834/2007 for organic production (EC, 2007). This requires a three-month drinking period in which the calves have to be provided with whole milk. Therefore, all experimental calves were weaned of milk at an age of 90 to $100 \mathrm{~d}$ and separated from their dams shortly afterwards (calves of the control group that were separated soon after birth were not studied). 
Table 1. Performance of cows without and with contact to their calves up to $100 \mathrm{~d}$ after calving depending on duration of contact and stage of lactation

\begin{tabular}{|c|c|c|c|c|}
\hline \multirow[b]{2}{*}{ Stage of lactation (DIM) } & \multirow[b]{2}{*}{ Control (No contact) } & \multicolumn{3}{|c|}{ Treatments (=daily duration of dam-calf contact) } \\
\hline & & Short-time $^{\mathrm{a}}(2 \times 15 \mathrm{~min})$ & Night-time (18:00-05:00) & Whole day $(24 \mathrm{~h})$ \\
\hline$>100 \ldots \leq 200$ & $23.1 \pm 5.84$ & $17.5 \pm 5.29$ & $24.5 \pm 5.29$ & $19.6 \pm 4.80$ \\
\hline$>200 \ldots \leq 305$ & $18.0 \pm 5.77$ & $12.8 \pm 3.46$ & $22.2 \pm 6.23$ & $15.0 \pm 3.78$ \\
\hline
\end{tabular}

Data presented as mean values \pm SD.

${ }^{\text {a }}$ Suckled before each milking.

All cows calved in individual calving pens. Cows of the control groups were separated from their calf within $24 \mathrm{~h}$ after calving. Cows of the treatment groups stayed with their calf at least $5 \mathrm{~d}$ in the calving pen before they were reintegrated into one of the two main herds consisting either of German Holstein or German Red Pied cows (a local dual purpose breed). Machine milking started with the first regular milking time after calving. All cows were milked twice per day at $5.30 \mathrm{a} . \mathrm{m}$. and 16.00 p.m. in a $2 \times 4$ tandem parlour (GEA Farm Technologies GmbH, Bönen, Germany) with following characteristics: vibration stimulation over $40 \mathrm{~s}$

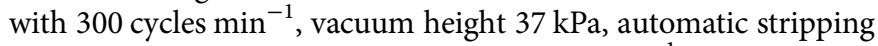
arm starting when the milk flow was $<800 \mathrm{~g} \mathrm{~min}^{-1}$ and automatic cluster removal at a milk flow $<300 \mathrm{~g} \mathrm{~min}^{-1}$. Milking routine comprised pre-milking, udder cleaning with a moist fabric towel, attaching and positioning of cluster. After cluster removal teats of the control cows were dipped while the teats of nursing cows were left untreated.

Calves were kept in a separate pen, where hay, silage and water were provided ad libitum. Concentrate feed was offered by an automatic feeder. Cows' laying area and the calves' outdoor run were connected via a responder and time controlled separation gate (Johnsen et al., 2016).

\section{Experimental design}

Times of cow-calf contact varied between the studies. In three studies calves of one group were allowed to enter the cows' area for $24 \mathrm{~h}$ and could suckle as they liked (=whole day calf driven contact). In one experiment the calves had access to the cows only between evening and morning milking (=night-time calf driven contact). During the day calves stayed in their own area. The third treatment comprised of a very short contact period: cows were moved to the calves' outdoor run shortly before milking times; for $15 \mathrm{~min}$ cows could nurse their calf and were then moved to the waiting area in front of the milking parlour (=shorttime contact). In total, records of 87 cows that had contact to their calves and 89 control cows were included.

All cows were subject to monthly milk recording for the whole lactation. Milk recording followed the rules of the ICAR (International Committee for Animal Recording, 2014) represented by the LKV Schleswig-Holstein e. V., the local animal recording association. Milk recording was a B S 42 control, which means that the recording was done by the farm staff, a representative sample of each milking time was collected, the intervals between the recordings were four weeks, and cows were milked twice per day. The fat and protein content as well as the somatic cell count (SCC) of the milk samples were determined at the laboratory of the LKV Schleswig-Holstein e. V. in Kiel, Germany, also according to the rules of ICAR.

\section{Statistical analysis}

Data analyses were done in R version 3.5.3 (R Core Team, 2019) using the package 'nlme' (Pinheiro et al., 2018) and ggplot2 (Wickham, 2016).

To achieve normal distribution data of SCC were $\log 10$-transformed.

Linear mixed models were used to analyse the data. Treatment (control, whole day, night-time, and short-time), opportunity of suckling during the first three month of lactation (yes/no), parity status (primiparous/multiparous), breed (German Holstein/ German Red Pied) and DIM were included as fixed effects. To take the repeated measurement into account, DIM and cow nested in experiment were included as random effects. The observed temporal correlation in the target variables was considered by applying an AR1 covariance structure. Model selection followed a stepwise backwards method starting with all possible interactions included. Interactions or variables were excluded when $P \geq 0.05$. However, no significant interactions between the explaining variables were observed. Effect of the treatments was in focus of this study, thus, treatment remained in the model even if no significant effect could be observed.

\section{Results}

As expected, the recorded milk yield during the three months, when cows of the treatment groups nursed their calf, was significantly lower than that of the control cows that were only milked. This difference was even larger when calves had whole day or short-time contact to their dams (Table 1).

Night-time contact did not increase the effect and after weaning no significant difference between control cows and cows with night-time contact could be found (Table 2). In contrast, the milk yield of the two other treatment groups stayed on a significantly lower level compared to the control cows (Table 2). Parity status, breed and DIM showed the expected significant effects on milk yield.

Fat content of milk was significantly lower during the months of nursing but reached the same level as in control cows after the calves were weaned (Table 2). In contrast to the fat percentage, protein content was significantly higher in nursing cows and also higher in milk of the dual purpose breed. First calving cows had less protein in their milk than older cows. 
Table 2. Model estimations of the investigated effects on milk yield, fat and protein content as well as SCC

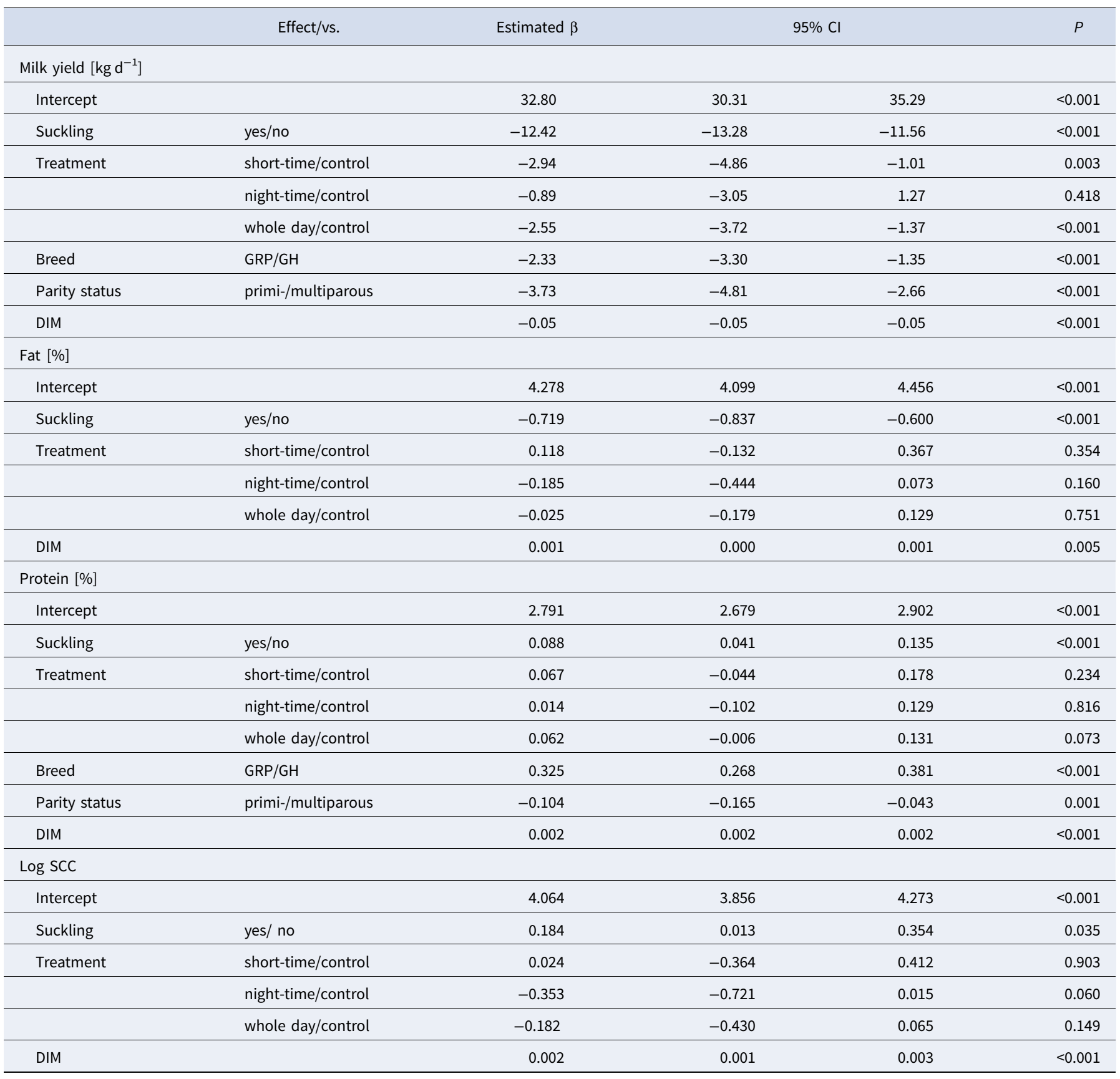

GRP, German Red Pied; GH, German Holstein; DIM, days in milk.

In general, SCC was low and only marginally affected during the suckling period. SCC differed between suckled and control cows by 12000 cells per mL (95\% CI: 618-30,470; Table 2).

\section{Discussion}

Suckler cows kept under semi-natural conditions nurse their calves 4 to 6 times per day depending on the stage of lactation/ age of the calf (Nicol and Sharafeldin, 1975). Milk intake can be up to $16 \mathrm{ld}^{-1}$ (Scholz et al., 2001). This value corresponds quite closely to the difference in milk yield between control cows and all cows that were suckled during the first three months of lactation in this study. However, after weaning and separation of the calves, cows that had whole day contact or nursed their calves twice per day produced significantly less milk than the control cows. This indicated a negative feed-back effect of these types of cow-calf contact on milk secretion. Machine milked cows secrete lower amounts of oxytocin than cows that are suckled, and cows used to nursing respond to machine milking with a disturbed milk ejection (Tančin and Bruckmaier, 2001). The milk remaining in the udder after an incomplete milking in combination with a constant milk secretion may lead to a return of milk from the udder cistern to the alveolar compartment (Caja et al., 2004) and a faster udder filling between milking times, both inducing a decline of milk secretion (Albaaj et al., 2018). This might especially explain the significantly lower milk yield 
of the cows that had only two times daily contact to their calf before they went to the waiting area and were machine milked together with the main herd. The limited time for suckling induced an incomplete milk removal, and after the disturbed release of oxytocin during machine milking more milk remained in the udder causing a decrease in milk secretion.

Dams with night-time contact did not react in the same way as cows with short-time contact. This is surprising, as suckling occurs usually during the daytime and often in early morning and late afternoon, at least in beef suckler calves (Odde et al., 1985). Although not documented, calves were seen suckling often before the cows were moved to the milking parlour for morning milking and in the evening, when cows came back from evening milking and were reunited with their calves, but seldom during the night. Thus, the frequency of milk removal in dams with night-time contact seemed not to differ from that of dams with short-time contact. However, calves with night-time contact could spend more time for suckling in the morning and probably induced a second, maybe even higher oxytocin excretion in the dam after evening milking to empty the udder completely, as was shown previously (de Passillé et al., 2008).

For cows with whole day contact, the frequency of milk removal went down from several times per day, due to the unrestricted suckling, to two times daily machine milking after the calves were separated. Bar-Peled et al. (1995) showed that the milk yield in cows that suckled three times daily in addition to three times daily machine milking dropped for one week when suckling was omitted, but achieved nearly the same level as cows whose machine milking frequency was changed from six times to three times daily. This was not the case in this study. Maybe the two times daily machine milking was insufficient to overcome the decrease in milk production after suckling stopped. Further studies should investigate the effect of an increased milking frequency after calf separation in cow-calf contact systems.

Milk fat content was only affected by nursing and not by the type of cow-calf contact. As adhesive and capillary forces influence the movement of the fat globules during the milking process (Ontsouka et al., 2003) and oxytocin stimulates the secretion of the fat droplets, as (Masedunskas et al., 2017) have shown in mice, the decreased fat percentage is an evidence for the disturbed milk ejection during machine milking of nursing cows.

Protein content was slightly, but significantly increased in nursing cows during the period of calf contact. This is in contrast to Bar-Peled et al. (1995) who did not find a difference between only machine milked and additionally suckled cows. In future, protein fractions should be analysed to investigate a possible effect of nursing on whey proteins.

There was no evidence that udder health of dams was impaired. SCC was marginally increased during the nursing period but not afterwards. This might be explained as a reaction against the additional strain applied to the teats when cows are milked and suckled.

In conclusion, milk yield and milk composition of cows is dissimilarly affected in different cow-calf contact systems. Further research should aim to clarify the effects of the suckling frequency and suckling time on the performance.

Acknowledgement. This article is based upon work from COST Action FA1308 DairyCare, supported by COST (European Cooperation in Science and Technology, www.cost.eu). COST is a funding agency for research and innovation networks. COST Actions help connect research initiatives across Europe and enable scientists to grow their ideas by sharing them with their peers. This boosts their research, career and innovation. Specifdically, I gratefully acknowledge COST for supporting the presentation of my research at the 5th DairyCare Conference in Thessaloniki, Greece, in 2018.

\section{References}

Albaaj A, Marnet PG, Hurtaud C and Guinard-Flament J (2018) Adaptation of dairy cows to increasing degrees of incomplete milk removal during a single milking interval. Journal of Dairy Science 101, 8492-8504.

Bar-Peled U, Maltz E, Bruckental I, Folman Y, Kali Y, Gacitua H, Lehrer AR, Knight CH, Robinson B, Voet H and Tagari H (1995) Relationship between frequent milking or suckling in early lactation and milk production of high producing dairy cows. Journal of Dairy Science 78, 2726-2736.

Barth K, Brückmann C, Häussermann A, Kälber T and Waiblinger S (2015) Effect of a nose flap on feeding behavior of dam reared dairy calves during weaning. In Kuratorium für Technik und Bauwesen in der Landwirtschaft KTBL (eds), Current Research in Applied Ethology. Darmstadt, Germany, pp. 139-147, KTBL (in German, English abstract).

Beaver A, Meagher RK, von Keyserlingk MAG and Weary DM (2019) Invited review: a systematic review of the effects of early separation on dairy cow and calf health. Journal of Dairy Science 102, 5765-5783.

Busch G, Weary DM, Spiller A and von Keyserlingk MAG (2017) American And German attitudes towards cow-calf separation on dairy farms. PLoS ONE 12, 1-20, doi: 10.1371/journal.pone.0174013

Caja G, Ayadi M and Knight CH (2004) Changes in cisternal compartment based on stage of lactation and time since milk ejection in the udder of dairy cows. Journal of Dairy Science 87, 2409-2415.

de Passillé AM, Marnet PG, Lapierre H and Rushen J (2008) Effects of twicedaily nursing on milk ejection and milk yield during nursing and milking in dairy cows. Journal of Dairy Science 91, 1416-1422.

European Commission (2007) Council Regulation (EC) No 834/2007 of 28 June 2007 on organic production and labelling of organic products and repealing Regulation (EEC) No 2092/91.

International Committee for Animal Recording (2014) ICAR Recording Guidelines. Edition 2014 Available at http://pecuaria.pt/docs/Guidelines_ 2014.pdf.

Johnsen JF, Zipp KA, Kälber T, de Passillé AM, Knierim U, Barth K and Mejdell CM (2016) Is rearing calves with the dam a feasible option for dairy farms?: current and future research. Applied Animal Behaviour Science 181, 1-11.

Masedunskas A, Chen Y, Stussman R, Weigert R and Mather IH (2017) Kinetics of milk lipid droplet transport, growth, and secretion revealed by intravital imaging: lipid droplet release is intermittently stimulated by oxytocin. Molecular Biology of the Cell 28, 935-946.

Meagher RK, Beaver A, Weary DM and von Keyserlingk MAG (2019) Invited review: a systematic review of the effects of prolonged cow-calf contact on behavior, welfare, and productivity. Journal of Dairy Science 102, 5765-5783.

Nicol AM and Sharafeldin MA (1975) Observations on the behaviour of single-suckled calves from birth to 120 days. Proceedings of the New Zealand Society of Animal Production 35, 221-230.

Odde KG, Kiracofe GH and Schalles RR (1985) Suckling behavior in range beef calves. Journal of Animal Science 61, 307-309.

Ontsouka CE, Bruckmaier RM and Blum JW (2003) Fractionized milk composition during removal of colostrum and mature milk. Journal of Dairy Science 86, 2005-2201.

Pinheiro J, Bates D, DebRoy S and Sarkar D and R Core Team (2018) nlme: Linear and Nonlinear Mixed Effects Models. [Online]. Available at https:// cran.r-project.org/package $=$ nlme

R Core Team (2019) R: A Language and Environment for Statistical Computing. [Online]. Vienna, Austria: R Foundation for Statistical Computing. Available at https://www.R-project.org

Roth BA, Barth K, Gygax L and Hillmann E (2009) Influence of artificial vs. mother-bonded rearing on sucking behaviour, health and weight gain in calves. Applied Animal Behaviour Science 119, 143-150.

Scholz H, Kovács AZ, Stefler J, Fahr R-D and von Lengerken G (2001) Milchleistung und -qualität von Fleischrindkühen während der 
Säugeperiode: (Milk yield and milk quality of beef cows during the suckling period). Archives Animal Breeding 44, 611-620.

Tančin V and Bruckmaier RM (2001) Factors affecting milk ejection and removal during milking and suckling of dairy cows. Veterinary Medicine - Czech 46, 108-118.

Wagner K, Barth K, Hillmann E, Palme R, Futschik A and Waiblinger S (2013) Mother rearing of dairy calves: reactions to isolation and to confrontation with an unfamiliar conspecific in a new environment. Applied Animal Behaviour Science 147, 43-54.

Wickham H (2016) ggplot2: Elegant Graphics for Data Analysis. [Online]. Cham: Springer. Available at http://dx.doi.org/10.1007/978-3-319-24277-4

Zipp KA, Barth K and Knierim U (2016) Behavioural response of dairy cows with and without calf-contact to hair of own and alien calves presented in the milking parlour. Applied Animal Behaviour Science 180, 11-17. 